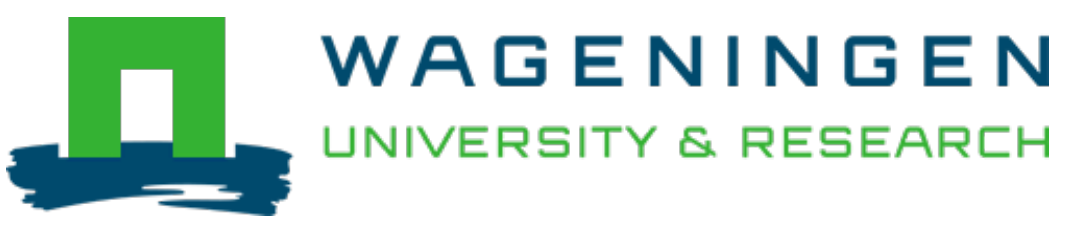

\title{
Postglacial migration of Populus nigra L.: lessons learnt from chloroplast DNA
}

Forest Ecology and Management

Cottrell, J.E.; Krystufek, V.; Tabbener, H.E.; Milner, A.D.; Connolly, T. et al

https://doi.org/10.1016/j.foreco.2004.10.052

This article is made publicly available in the institutional repository of Wageningen University and Research, under the terms of article $25 \mathrm{fa}$ of the Dutch Copyright Act, also known as the Amendment Taverne. This has been done with explicit consent by the author.

Article $25 \mathrm{fa}$ states that the author of a short scientific work funded either wholly or partially by Dutch public funds is entitled to make that work publicly available for no consideration following a reasonable period of time after the work was first published, provided that clear reference is made to the source of the first publication of the work.

This publication is distributed under The Association of Universities in the Netherlands (VSNU) 'Article $25 \mathrm{fa}$ implementation' project. In this project research outputs of researchers employed by Dutch Universities that comply with the legal requirements of Article $25 \mathrm{fa}$ of the Dutch Copyright Act are distributed online and free of cost or other barriers in institutional repositories. Research outputs are distributed six months after their first online publication in the original published version and with proper attribution to the source of the original publication.

You are permitted to download and use the publication for personal purposes. All rights remain with the author(s) and / or copyright owner(s) of this work. Any use of the publication or parts of it other than authorised under article $25 \mathrm{fa}$ of the Dutch Copyright act is prohibited. Wageningen University \& Research and the author(s) of this publication shall not be held responsible or liable for any damages resulting from your (re)use of this publication.

For questions regarding the public availability of this article please contact openscience.library@,wur.nl 


\title{
Postglacial migration of Populus nigra L.: lessons learnt from chloroplast DNA
}

\author{
J.E. Cottrell $^{\mathrm{a}, *}$, V. Krystufek ${ }^{\mathrm{b}}$, H.E. Tabbener ${ }^{\mathrm{a}}$, A.D. Milner ${ }^{\mathrm{a}}$, T. Connolly ${ }^{\mathrm{a}}$,

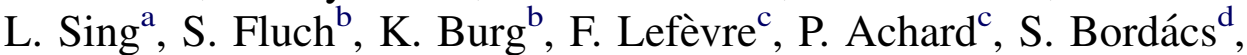 \\ K. Gebhardt ${ }^{\mathrm{e}}$, B. Vornam ${ }^{\mathrm{f}}$, M.J.M. Smulders ${ }^{\mathrm{g}}$, A.H. Vanden Broeck ${ }^{\mathrm{h}}$,
} J. Van Slycken ${ }^{\mathrm{h}}$, V. Storme ${ }^{\mathrm{i}}$, W. Boerjan ${ }^{\mathrm{i}}$, S. Castiglione ${ }^{\mathrm{i}}$, T. Fossati ${ }^{\mathrm{j}}$, N. Alba $^{\mathrm{k}}$, D. Agúndez ${ }^{\mathrm{k}}$, C. Maestro ${ }^{1}$, E. Notivol ${ }^{1}, J_{\text {. Bovenschen }}^{\mathrm{m}}$, B.C. van Dam ${ }^{\mathrm{m}}$

${ }^{a}$ Forest Research, Northern Research Station, Roslin, Midlothian, Scotland EH25 9SY, UK

${ }^{\mathrm{b}}$ Austrian Research Centre Siebesdorf (ARCS), A-2444 Siebersdorf, Austria

${ }^{\mathrm{c}}$ INRA, Av. A. Vivaldi, 8400 Avignon, France

${ }^{\mathrm{d}}$ National Institute for Agricultural Quality Control, Forestry Department, H-1024 Keleti K. u.24, Budapest, Hungary

${ }^{\mathrm{e}}$ Hessian Forest Centre, Prof. Oelkers-Str. 6, D-34346 Hann. Muenden, Germany

${ }^{\mathrm{f}}$ Institute of Forest Genetics and Tree Breeding, Büsgenweg 2, 37077 Göttingen, Germany

${ }^{\mathrm{g}}$ Plant Research International, Wageningen, The Netherlands

${ }^{\mathrm{h}}$ Institute for Forestry and Game Management (IFG), Research Station of the Flemish Community, Gaverstraat 4, $B 9500$ Geraardsbergen, Belgium

${ }^{\mathrm{i}}$ Department of Plant Systems Biology, Flanders Interuniversity Institute for Biotechnology (VIB), Ghent University, Technologiepark 927, B-9052 Gent, Belgium

${ }^{\mathrm{j}}$ Università degli Studi di Milano, Dipartimento di Biologia (UVM), Sezione di Botanica Generale, Via Celoria 26, Torre CI-20133, Milano MI, Italy

${ }^{\mathrm{k}}$ National Institute for Agrarian and Food Research (Instituto Nacional de Investigación Agraria y Alimetaria I.N.I.A.),

Crta de la Coruña, km 7.5, 28040 Madrid, Spain

${ }^{1}$ SIA-DGA, Zaragoza, Spain

${ }^{\mathrm{m}}$ P.O. Box 47, 6700 AA Wageningen, The Netherlands

Received 14 October 2003; received in revised form 28 July 2004; accepted 12 October 2004

\begin{abstract}
Eleven laboratories have collaborated to study chloroplast DNA (cpDNA) variation in black poplar (Populus nigra L.) across Europe in order to improve our understanding of the location of glacial refugia and the subsequent postglacial routes of recolonisation. A common analysis based on the restricted fragments produced by five primer pairs was used to determine the cpDNA haplotype of 637 samples obtained from genebank collections established in nine European countries. Haplotype 2 was particularly common and was found in $46 \%$ of the non-hybrid samples. A total of 81 non-hybrid chloroplast variants were
\end{abstract}

\footnotetext{
* Corresponding author. Tel.: +44 131445 6921; fax: +44 1314455124

E-mail address: joan.cottrell@forestry.gsi.gov.uk (J.E. Cottrell).
} 
detected. Three haplotypes (from four trees believed to originate from Eastern Europe) clustered together and were very different from the rest of the samples. The remaining samples were divided into two groups, one of which had a largely eastern distribution and samples from the other group were mostly located in the west. This, along with the fact that Spain in the southwest and Austria and Italy in the southeast had high diversity, suggest that there were ice age refugia of black poplar in both southwestern (Spain) and southeastern Europe (Italy and/or Balkan). Results also indicate that the Pyrenees formed a significant barrier, since only 7 of the 45 haplotypes in Spain exist elsewhere in Europe.

(C) 2004 Elsevier B.V. All rights reserved.

Keywords: Postglacial colonisation; Refugia; Populus nigra; Black poplar

\section{Introduction}

European black poplar (Populus nigra L.) is a pioneer species of riparian ecosystems. Flowers are wind pollinated and seed is largely wind dispersed. Vegetative propagules are disseminated both by water and by human activity. Regeneration of $P$. nigra by seed takes place through colonisation of newly perturbed sites and scattered trees are more frequent than huge stands. The species has a natural distribution ranging from North Africa and Ireland in the west, across to Russia and China in the east (Zsuffa, 1974).

The abundance of black poplar is threatened due to the loss of its natural habitat by urbanisation, drainage of wetlands for agricultural use and canalisation of rivers for flood prevention. At one time its wood was highly prized because it is lightweight, resistant to fire and has excellent shock absorbing qualities. As a result, it has a long history of use for clogs, fruit baskets, furniture, flooring sheep hurdles and wagons. However, human mediated propagation of the species declined in the 19th century when the faster growing hybrid $P . \times$ euramericana was introduced to northern Europe. $P$. nigra is now recognised to be endangered and it has, therefore, been listed as one of the important species in need of conservation in the Strasbourg resolution of 1990 for the protection of forest trees in Europe (Anonymous, 1990; Arbez and Lefèvre, 1997). Black poplar is an important component of interspecific poplar breeding programmes and both conservationists and tree breeders are aware of how important it is to protect the species.

In an attempt to conserve the genetic diversity that remains within this endangered species several European countries have independently set up ex situ genebanks in which cuttings of native black poplars from within each country are grown. Since 1994, the co-ordination of national conservation initiatives at the European level has been achieved through the EUFORGEN Populus nigra Network (Lefèvre et al., 1998). Among its different tasks for ex situ conservation, the Network has developed a European database of national genebanks (www.ipgri.cgiar.org) and a core collection of $P$. nigra clones has been established, which is representative of the whole geographic range of the species. This paper reports the results of a survey of chloroplast DNA (cpDNA) variation in the genebanks in seven European countries. The original locations of the genotypes that were contained in the genebanks were used to determine the distribution of the various cpDNA haplotypes in Europe. The objective of this paper is to use this information to locate the postglacial refugia of black poplar and to determine the postglacial routes of colonisation of this species. Information regarding the distribution of cpDNA diversity is valuable in developing conservation policy as the colonising effect is known to have a major influence on the structure and distribution of existing diversity within a species. The amount of diversity within collections with nuclear markers (isozymes, AFLP, microsatellites is reported elsewhere (Storme et al., 2004)).

The genebanks provided an excellent source of material based on collections made by people who were both knowledgeable regarding the locations of natural populations and able to distinguish $P$. nigra from hybrid material on the basis of morphology. This saved the time and expense of travelling throughout Europe to collect samples. The collections did however, have the disadvantage that only one sample per population was usually included and this prevented any comparison of within and between population diversity from being made. Also, in those genebanks, which had been set up as a breeding rather 
than a conservation resource, there had been no attempt to make an equal geographic sampling of the material which existed within each country. However, these aspects do not preclude an analysis of the distribution of chloroplast haplotypes in order to understand the recolonisation of Europe by P. nigra after the last ice age.

Ice ages occur at regular intervals of 100,000 years with warm interglacial periods lasting $15-20,000$ years as a result of instabilities in the earth's climate caused by Milankovitch cycles (Bennett, 1990). Many trees common in northern Europe today survived these glacial periods as small, low-density populations in refugia in deep valleys between the mountains of southern Europe (Bennett et al., 1991). Fossil pollen maps of European deciduous oaks indicate refugia in southern Spain, southern Italy and the Balkan peninsula (Huntley and Birks, 1983; Bennett et al., 1991). However, unlike other species, pollen records are of little value in determining the colonisation routes of P. nigra. This is partly because Populus pollen has been found to be present in very low quantities in sampled pollen cores and also because it is impossible to distinguish the pollen of $P$. nigra from that of $P$. alba and $P$. tremula. Therefore, there is, in poplar, a particular requirement for an alternative method to determine the postglacial routes of colonisation. This is now available in the form of cpDNA methodology, which offers a significant technological advance that can be used to provide the first insight into the postglacial colonisation routes of black poplar in Europe.

Many universal primers have been developed for the chloroplast genome of Nicotiana tabacum (Heinze, 1998a,b; Samuel et al., 1997; Démesure et al., 1995; Dumolin-Lapègue et al., 1997; Weising and Gardner, 1999; Petit et al., 2002a). These regions of the chloroplast genome have provided useful information for biodiversity in a range of species (Démesure et al., 1995; Heinze, 1998a,b; Lagercrantz et al., 1997; King and Ferris, 1998; Petit et al., 2002a,b). In these species, the uniparental mode of inheritance, the absence of recombination and the low mutation rate make this genome an appropriate source of markers for phylogenetic studies as well as for the study of postglacial routes of colonisation. Maternally inherited genomes are more geographically structured, due to limited seed dispersal compared to pollen movement (El Mousadik and Petit, 1996).
The cpDNA genome has been extensively studied in poplar using both the RFLP and the PCR approach (Smith and Sytsma, 1990; Mejnartowicz, 1991; Rajora and Dancik, 1992, 1995a,b,c; Sabsch, 1992; Vornam et al., 1994; Heinze, 1998a,b). Initial interest was directed at the development of species-specific markers and whereas Smith and Sytsma (1990) found no interspecific variation, several others demonstrated interspecific variation between $P$. nigra and P. deltoides (Vornam et al., 1994; Rajora and Dancik, 1995a,b,c; Heinze, 1997; Krystufek, 2001; Krystufek et al., 2002). Intraspecific variation was also detected in P. nigra, as well as in several other poplar species (Sabsch, 1992; Rajora and Dancik, 1995a; Heinze, 1998a; Krystufek, 2001). In many cases this intraspecific variation was dependent on the geographic origin of the maternal line of the tested material. The maternal inheritance of cpDNA in poplar was first demonstrated in controlled crosses by Mejnartowicz (1991), and this mode of inheritance was later confirmed by Rajora and Dancik (1992). However, in a later paper Rajora and Dancik (1995c) questioned the finding that cpDNA is entirely maternally inherited in poplar. The variants found in the $P$. $\times$ euramericana hybrids that were studied had not been detected in any P. deltoides, which had previously been studied. This finding did not fit with the belief that this species had acted as the maternal parent of these hybrids. Rajora and Dancik (1995a) suggest that this represents evidence that cpDNA is not entirely maternally inherited in poplar and that there may be parental recombination in $P . \times$ euramericana hybrid clones. This is an important consideration, as it would render the cpDNA molecule unsuitable for phylogenetic studies in poplar. This phenomenon has been detected in other species but not in any other studies involving poplar. Heinze (1998b) is sceptical that these results do indeed present evidence of cpDNA paternal leakage. Instead, he suggests that the results may be due to the existence of undetected cpDNA variants in $P$. deltoides or to probe contamination. In addition, Heinze (1998b) points out that as these results are confined to one particular probe which covers a region which is known to be a mutation hotspot in other species and as these results were detected in hybrids they may reflect sequence instability in hybrids rather than evidence of paternal leakage of cpDNA. Therefore, taken in its entirety, the balance of evidence indicates that cpDNA in $P$. nigra is maternally inherited and therefore 
variation in the cpDNA molecule has been used in this paper to study postglacial routes of colonisation.

Although no detailed data exist on the distribution of cpDNA variation in black poplar such information exists for Alnus glutinosa L. (black alder), which is also a wind pollinated tree species of riparian and waterlogged habitats (King and Ferris, 1998). Alder is common in Europe and the Mediterranean and extends as far as the mountains of Turkey and North Africa. The cpDNA results show that most of northern Europe was colonised from a refuge in the Carpathian region (Hungary and Romania), although two further refugia in Spain and Turkey are suggested. One of the objectives of the current study was to determine whether current populations of $P$. nigra, a species, which has much in common with black alder in ecological terms, originate from the same refugia. Additionally, this study aimed to determine how the diversity in cpDNA haplotypes is distributed across Europe.

\section{Materials and methods}

\subsection{Material}

A consortium of 11 laboratories in 9 European countries participated in this EU funded project. One of the project objectives was to develop appropriate cpDNA markers that could be used to assess the diversity, which had been captured in the genebanks set up by each country for ex situ conservation of $P$. nigra. A total of 637 samples from genebanks in seven countries were analysed (Table 1). Detailed information about sampling locations is available on the EUFORGEN web pages.

\subsection{DNA extraction and analysis}

DNA was extracted from young leaves using QIAGEN plant Dneasy mini kits according to the manufacturer's instructions (http://www.qiagen.com). Details of the genebanks and the number of samples analysed by each laboratory are listed in Table 1 . The five primer pairs that were used in the study are described by Fluch et al. (2002) and are listed in Table 2. The optimised cpDNA primers and appropriate restriction enzymes (Table 3) were optimised for
P. nigra in the Austrian laboratory and distributed to the other participating laboratories with detailed instructions on how to perform the analysis. The EUFORGEN Core Collection (Vietto, 2000) was used to provide reference samples against which banding patterns from the genebank samples could be compared. Several hybrid and non-hybrid P. nigra poplar samples were also included as references. Novel bands and new haplotypes, which were discovered in the course of the genebank survey, were checked by the Austrian laboratory before being included in the database. This precaution was implemented to reduce misscoring errors that might otherwise have arisen because the gels were run and scored in several different laboratories. The gels showing the banding patterns obtained for each primer/restriction enzyme combination and the results obtained for the EUFORGEN core collection and a range of interspecific crosses are presented by Krystufek (2001). Unfortunately, in the current survey, some of the primer/restriction enzyme combinations failed in certain laboratories. In particularly, the ORF$\mathrm{M} E c o$ RI failed to work in the Italian laboratory, the DT $M n l I$ failed with the Spainish samples and $17+20$ HinfI failed in France.

PCR reactions were set up in $25 \mu \mathrm{l}$ aliquots using the following components: $15 \mu \mathrm{l}$ sterile distilled water, $2.5 \mu \mathrm{l} 10 \times$ reaction buffer, $0.8 \mu \mathrm{l} 50 \mathrm{mM}$ $\mathrm{MgCl}_{2}, 0.4 \mu \mathrm{l} \mathrm{W}-1$ (1\%), $0.4 \mu \mathrm{l}$ BSA $(20 \mathrm{mg} / \mathrm{ml})$, $0.365 \mu \mathrm{l} \quad \mathrm{dNTP} \quad(10 \mathrm{mM}), \quad 0.024 \mu \mathrm{l}$ primer 1 $(100 \mu \mathrm{M}), 0.024 \mu \mathrm{l}$ primer $2(100 \mu \mathrm{M}), 0.3 \mu \mathrm{l}$ Taq polymerase $(5 \mathrm{U} / \mu \mathrm{l})$ and $5 \mu \mathrm{l}$ DNA (5:95 dilution). The primers were supplied by Amersham Pharmacia Biotech and all other PCR components by Gibco BRL.

The PCR conditions for DT, CD and TF were as follows: $95{ }^{\circ} \mathrm{C}$ for $15 \mathrm{~min}$, followed by 40 cycles of $\left(93{ }^{\circ} \mathrm{C}\right.$ for $45 \mathrm{~s}, 55^{\circ} \mathrm{C}$ or $58{ }^{\circ} \mathrm{C}$ (see Table 2) for $45 \mathrm{~s}$ and $72{ }^{\circ} \mathrm{C}$ for $2 \mathrm{~min}$ ) followed by $72{ }^{\circ} \mathrm{C}$ for $10 \mathrm{~min}$. For ORF-M there was an initial step of $95{ }^{\circ} \mathrm{C}$ for 15 min followed by 30 cycles of $\left(95^{\circ} \mathrm{C}\right.$ for $50 \mathrm{~s}, 55^{\circ} \mathrm{C}$ for $50 \mathrm{~s}$ and $70{ }^{\circ} \mathrm{C}$ for $1 \mathrm{~min}$ ) followed by $70{ }^{\circ} \mathrm{C}$ for $10 \mathrm{~min}$. The PCR conditions for $17+20$ were $95^{\circ} \mathrm{C}$ for $15 \mathrm{~min}$ followed by 20 cycles of $\left(95^{\circ} \mathrm{C}\right.$ for $50 \mathrm{~s}$, $58{ }^{\circ} \mathrm{C}$ for 50 s with a reduction of $0.5{ }^{\circ} \mathrm{C}$ per cycle and $72{ }^{\circ} \mathrm{C}$ for $1 \mathrm{~min} 45 \mathrm{~s}$ ) followed by a further 20 cycles of $\left(95^{\circ} \mathrm{C}\right.$ for $50 \mathrm{~s}, 50{ }^{\circ} \mathrm{C}$ for $50 \mathrm{~s}$ and $70{ }^{\circ} \mathrm{C}$ for $1 \mathrm{~min}$ $45 \mathrm{~s}$ ) followed by $72{ }^{\circ} \mathrm{C}$ for $10 \mathrm{~min}$.

The PCR products were then digested using the restriction enzymes shown in Table 3 . The $15 \mu \mathrm{l}$ 
Table 1

Details of the location and establishment date of each genebank along with the number of samples from individual genebank and the laboratory responsible for the cpDNA analysis

\begin{tabular}{|c|c|c|c|c|c|}
\hline Country & $\begin{array}{l}\text { Genebank date of } \\
\text { establishment }\end{array}$ & $\begin{array}{l}\text { Number of } \\
\text { ramets }\end{array}$ & $\begin{array}{l}\text { Number } \\
\text { of trees }\end{array}$ & Laboratory for analysis & Location of genebank \\
\hline Netherlands & 1986 & 240 & 79 & Alterra, Wageningen & De Moerhoek, Dronten \\
\hline France & $>1970$ & 500 & 64 & INRA, Avignon & $\begin{array}{l}\text { National Commission for the } \\
\text { Conservation of Forest } \\
\text { Genetic Resources }\end{array}$ \\
\hline \multirow[t]{2}{*}{ Spain } & 1980 & 110 & 75 & $\begin{array}{l}\text { Austrian Research } \\
\text { Centre, Siebersdorf }\end{array}$ & SIA-DGA Zaragoza \\
\hline & 1990 & 45 & 25 & $\begin{array}{l}\text { Austrian Research } \\
\text { Centre, Siebersdorf }\end{array}$ & INIA, Madrid \\
\hline Belgium & $1958-2003$ & 250 & 84 & VIB, Gent, Belgium & IFG, Geraardsbergen, \\
\hline Austria & 1998 & 180 & 100 & $\begin{array}{l}\text { Austrian Research } \\
\text { Centre, Siebersdorf }\end{array}$ & $\begin{array}{l}\text { Austrian Federal Office and Research } \\
\text { Centre for Forests (BFW) }\end{array}$ \\
\hline Italy & & 400 & 74 & $\begin{array}{l}\text { Università degli Studi } \\
\text { di Milano, Milan }\end{array}$ & Casale Monferrato \\
\hline UK & 1993-1995 & 100 & 87 & Forest Research, Roslin & $\begin{array}{l}\text { Talybont, Fineshade and } \\
\text { Downham Market }\end{array}$ \\
\hline Germany & 1970 & 370 & 22 & $\begin{array}{l}\text { Institute of Forest } \\
\text { Genetics and Forest } \\
\text { Tree Breeding, University } \\
\text { of Göttingen }\end{array}$ & Hessen-Forst Hann. Muenden \\
\hline Hungary & 1950 & & 31 & $\begin{array}{l}\text { OMMI, Department of } \\
\text { Forestry, Budapest }\end{array}$ & $\begin{array}{l}\text { Forestry Gene Bank Sárvár, } \\
\text { managed by Hungarian Forest } \\
\text { Research, established } \\
\text { by Ferenc Kopecky }\end{array}$ \\
\hline
\end{tabular}

digestion mixture contained $2 \mu 110 \times$ buffer, $0.5 \mu l$ restriction enzyme $(10 \mathrm{U} / \mu \mathrm{l})$ and $12.5 \mu \mathrm{l}$ sterile distilled water. $5 \mu \mathrm{l}$ of amplified PCR product was added to $15 \mu \mathrm{l}$ of digestion mixture. Following digestion, $5 \mu \mathrm{l}$ of bromophenol blue was added to $12.5 \mu \mathrm{l}$ of digestion product and each sample was loaded on to a $8 \%$ polyacrylamide gels. After electrophoresis at $250 \mathrm{~V}$ for $4.5 \mathrm{~h}$ the bands were visualised using a silver staining system.

\subsection{Phylogenetic analysis}

The data were scored as multistate, unordered characters in which each restriction fragment was a character and the multistates were the different sizes of each fragment. The most common fragment size was assigned as 1 and other size fragments were numbered in order of decreasing frequency. Two methods of analysis were applied to the dataset of 94 unique haplotypes. The first method involved the construction of a genetic distance matrix based on
Jaccard similarity coefficients. All the points were then connected in a minimum spanning tree using the software package Genstat (Payne et al., 1993). This procedure connects haplotypes by direct links, which have the smallest possible total length (Prim, 1957). The data were also analysed using the Fitch algorithm in the PHYLIP 3.5 computer package (Felsenstein, 1993) in order to construct a phylogenetic tree. The Fitch analysis estimates phylogenies from distance matrix data using the 'additive tree model' where the distances are expected to equal the sums of branch lengths between taxa (Petit et al., 2002a).

\section{Results}

\subsection{Classification and relatedness of cpDNA haplotypes}

The classification into individual haplotypes was complicated by the fact that data were missing for 
certain primer/restriction enzyme combinations in several countries. A strategy was therefore adopted where unique haplotypes were identified based on complete sets of data at all primer/restriction enzyme combinations. Samples with incomplete data were then compared with haplotypes based on complete data sets. If a sample with an incomplete data set did not differ from a haplotype with a complete dataset it was considered to be the same haplotype but was given a suffix to indicate that this was based on an incomplete data set. For example, if a sample with a complete data set was called haplotype 1, a sample which matched this sample but had missing data at a given primer/restriction enzyme was called haplotype 1a. Another sample which also matched haplotype 1 but had missing data at a different primer/restriction enzyme was called haplotype 1b. Samples which had missing data but did not match a sample with a complete dataset were allocated a unique haplotype number. The list of haplotypes along with their banding patterns is presented in Table 4. A total of 94 unique haplotypes, based on six primer/restriction enzyme combinations, was detected in the 637 trees analysed in this study.

The two methods used to assess relatedness, namely the minimum spanning tree and the Fitch analysis, largely agreed with one another (Fig. 1a and b). The haplotypes could be divided into four groups. With the exception of haplotype 90, both analyses clearly separated the samples that were suspected hybrids (on the basis of morphology) from the nonhybrid P. nigra samples. Haplotype 90, a suspected hybrid, had missing data and this may account for its unexpected position in the relatedness trees (Table 4). Alternatively, although it was suspected of being a hybrid it may in fact have been a pure black poplar. The hybrid haplotypes were called Group I. In total, this represented only 22 samples consisting of 11 haplotypes, which indicates that less than $4 \%$ of the genebank trees are hybrid in origin. The majority (73\%) of these hybrid trees came the Belgian and Dutch genebanks. They consistently differed from the non-hybrids at CD EcoRI-1 and CD EcoRI-2 (Table 4). Their haplotypes were similar but not identical to those of $P$. deltoides $\times P$. nigra controlled crosses tested by Krystufek (2001) using the same primer/enzyme combinations. This, combined with their morphology indicates that they were probably 
Table 3

The restriction enzyme, restriction temperature and number of fragments that were obtained for each cpDNA region that was studied

\begin{tabular}{lllll}
\hline $\begin{array}{l}\text { CpDNA } \\
\text { fragment }\end{array}$ & $\begin{array}{l}\text { Restriction } \\
\text { enzyme }\end{array}$ & $\begin{array}{l}\text { Restriction } \\
\text { temperature }\left({ }^{\circ} \mathrm{C}\right)\end{array}$ & $\begin{array}{l}\text { Restriction } \\
\text { time (h) }\end{array}$ & $\begin{array}{l}\text { Number of } \\
\text { fragments (I-V) and } \\
\text { number of variants } \\
\text { per fragment (1-4) } \\
\text { in the genebanks }\end{array}$ \\
\hline $\mathrm{CD}$ & & & & $\mathrm{I}(4), \mathrm{II}(3), \mathrm{III}(3), \mathrm{IV}(4), \mathrm{V}(3)$ \\
$\mathrm{CD}$ & EcoRI & 37 & 3 & $\mathrm{I}(4), \mathrm{II}(2), \mathrm{III}(2), \mathrm{IV}(5), \mathrm{V}(3)$ \\
$\mathrm{TF}$ & TaqI & 65 & 3 & $\mathrm{I}(3), \mathrm{II}(3), \mathrm{III}(4)$ \\
$\mathrm{DT}$ & TaqI & 65 & 3 & $\mathrm{I}(6), \mathrm{II}(4), \mathrm{III}(4)$ \\
$\mathrm{ORF}-\mathrm{M}$ & MnII & 37 & 3 & $\mathrm{I}(4), \mathrm{II}(6)$ \\
$17+20$ & EcoRI & 37 & 3 & $\mathrm{I}(7), \mathrm{II}(2), \mathrm{III}(3)$ \\
\hline
\end{tabular}

P. $\times$ euramericana hybrids. These 11 haplotypes were excluded from subsequent analysis for the determination of postglacial routes of colonisation.

The relatedness analysis (particularly the Fitch) also clearly distinguished haplotypes 79,80 and 81 as a separate group (Group II). This group consisted of three samples from Germany and one from Hungary. The original locations from which these samples had been taken was not recorded for the three German samples although when the records relating to the German genebanks were examined in more detail it emerged that the trees which were haplotypes 79 and 80 were fastigiate in form. They were poplars that had been grown as ornamentals and were not native to Germany but were believed to be of eastern European origin.

The distribution of the remaining samples is illustrated in Fig. 2a-d. These samples could be divided into two groups consisting of Group III, which had a largely eastern distribution and Group IV, which exhibited a more western distribution (Figs. 2 and 3). The division of the samples into Group III and Group IV shown in Table 4 is based on the minimum spanning tree analysis and the Fitch analysis largely, though not entirely agrees with this division. The majority of samples belonged to Group IV. In the Fitch analysis the haplotypes from Italy (haplotypes 5, 13, $22,23,24$ and 25) are located in an intermediate position between Group III and Group IV. In the minimum spanning tree some of the Italian haplotypes (haplotypes 23 and 24) cluster with the eastern European samples and the others (haplotypes 5, 13, 20, 22 and 25) group with samples originating from the west. The Italian samples have unique bands for several of the TF TaqI-1 and DT MnI-1 fragments
(Table 4). It is therefore difficult to interpret how closely related these Italian samples are to the rest of the material that was analysed.

Table 5 shows the number of non-hybrid haplotypes that were present in latitude categories of two degrees. The number of samples was different in each latitude category. However, a chi square test showed that there is statistically significant evidence $(p<0.01)$ to reject the hypothesis that the number of haplotypes depends on the number of samples regardless of latitude. The southern latitudes contained a higher diversity with fifty-one of the haplotypes being restricted to latitudes below $46^{\circ} \mathrm{N}$. This large number is disproportional to the number of samples taken from this region and is consistent with the notion of glacial refugia in southern Europe.

\subsection{Distribution of haplotypes}

In total, the genebanks that were sampled contained 83 non-hybrid haplotypes. From this total, 50 were only represented by a single sample and a further 16 were only present in two or three samples. The distribution of the majority of haplotypes (85\%) was restricted to a single country and only 11 haplotypes occurred in more than one country (Table 6). Thirtyeight haplotypes were restricted to Spain. In Austria, Italy, France and Germany between five and seven haplotypes occurred which were unique to one particular country. Northern countries also had some unique haplotypes with four in Belgium, three in the Netherlands and one in Britain. Hungary only had three haplotypes of which two only occurred there (Table 6). 
Table 4

The banding pattern of each haplotype produced with the six primer/restriction enzyme combinations

\begin{tabular}{llllllllllllllllllllllll}
\hline Haplotype & Group & $\mathrm{CD}$ & $\mathrm{CD}$ & $\mathrm{CD}$ & $\mathrm{CD}$ & $\mathrm{CD}$ & $\mathrm{CD}$ & $\mathrm{CD}$ & $\mathrm{CD}$ & $\mathrm{CD}$ & $\mathrm{CD} T a q$ & $\mathrm{TF}$ & $\mathrm{TF}$ & $\mathrm{TF}$ & $\mathrm{DT}$ & $\mathrm{DT}$ & $\mathrm{DT}$ & $\mathrm{ORF}-\mathrm{M}$ & $\mathrm{ORF}-\mathrm{M}$ & $17+20$ & $17+20$ & $17+20$
\end{tabular}

\begin{tabular}{|c|c|c|c|c|c|c|c|c|c|c|c|c|c|c|c|c|c|c|c|c|c|c|}
\hline & & EcoRI-1 & EcoRI-2 & EcoRI-3 & EcoRI-4 & EcoRI-5 & TaqI-1 & TaqI-2 & TaqI-3 & $\begin{array}{l}\text { CD } \\
\text { TaqI-4 }\end{array}$ & I-5 Iaq & TaqI-1 & $\begin{array}{l}\text { Taq } \\
\text { Taq-2 }\end{array}$ & TaqI -3 & MnlI-1 & MnII-2 & Mnll-3 & EcoRI-1 & EcoRI-2 & HinfI-1 & $\begin{array}{l}11+20 \\
\text { Hinfl-2 }\end{array}$ & Hinff-3 \\
\hline 1 & III & 1 & 1 & 1 & 1 & 1 & 1 & 1 & 1 & 1 & 1 & 1 & 1 & 1 & 1 & 1 & 1 & 1 & 1 & 0 & 1 & 1 \\
\hline 2 & III & 1 & 1 & 1 & 1 & 1 & 1 & 1 & 1 & 1 & 1 & 1 & 1 & 1 & 1 & 1 & 1 & 1 & 1 & 1 & 1 & 1 \\
\hline $2 a$ & III & 1 & 1 & 1 & 1 & 1 & 1 & 1 & 1 & 1 & 1 & 1 & 1 & 1 & 1 & 1 & 1 & & & 1 & 1 & 1 \\
\hline $2 b$ & III & 1 & 1 & 1 & 1 & 1 & 1 & 1 & 1 & 1 & 1 & 1 & 1 & 1 & & & & 1 & 1 & 1 & 1 & 1 \\
\hline $2 \mathrm{c}$ & III & 1 & 1 & 1 & 1 & 1 & 1 & 1 & 1 & 1 & 1 & 1 & 1 & 1 & 1 & 1 & & 1 & 1 & 1 & 1 & 1 \\
\hline $2 \mathrm{~d}$ & III & 1 & 1 & 1 & 1 & 1 & 1 & 1 & 1 & 1 & 1 & 1 & 1 & 1 & 1 & 1 & 1 & 1 & & & & \\
\hline $2 \mathrm{e}$ & III & 1 & 1 & 1 & 1 & 1 & 1 & 1 & 1 & 1 & 1 & 1 & 1 & 1 & 1 & 1 & 1 & 1 & 1 & & & \\
\hline 3 & III & 1 & 1 & 1 & 1 & 1 & 1 & 1 & 1 & 1 & 1 & 1 & 1 & 1 & 1 & 1 & 1 & 1 & 1 & 1 & 1 & 2 \\
\hline 4 & III & 1 & 1 & 1 & 1 & 1 & 1 & 1 & 1 & 1 & 1 & 1 & 1 & 1 & 1 & 1 & 1 & 1 & 1 & 2 & 1 & 1 \\
\hline $4 \mathrm{a}$ & III & 1 & 1 & 1 & 1 & 1 & 1 & 1 & 1 & 1 & 1 & 1 & 1 & 1 & 1 & 1 & 1 & & & 2 & 1 & 1 \\
\hline 16 & III & 1 & 1 & 1 & 1 & 1 & 1 & 1 & 1 & 1 & 1 & 1 & 1 & 1 & 2 & 1 & 1 & 1 & 1 & 2 & 1 & 1 \\
\hline $16 a$ & III & 1 & 1 & 1 & 1 & 1 & 1 & 1 & 1 & 1 & 1 & 1 & 1 & 1 & 2 & 3 & 1 & & & 2 & 1 & 1 \\
\hline 17 & III & 1 & 1 & 1 & 1 & 1 & 1 & 1 & 1 & 1 & 1 & 1 & 1 & 1 & 2 & 3 & 1 & 1 & 1 & 2 & 1 & 1 \\
\hline 26 & III & 1 & 1 & 1 & 1 & 1 & 1 & 1 & 1 & 3 & 1 & 1 & 1 & 1 & 1 & 1 & 1 & 1 & 1 & 1 & 1 & 1 \\
\hline $26 a$ & III & 1 & 1 & 1 & 1 & 1 & 1 & 1 & 1 & 3 & 1 & 1 & 1 & 1 & 1 & 1 & 1 & & . & 1 & 1 & 1 \\
\hline 10 & III & 1 & 1 & 1 & 1 & 1 & 1 & 1 & 1 & 1 & 1 & 1 & 1 & 1 & 1 & 1 & 2 & 1 & 1 & 1 & 1 & 1 \\
\hline 11 & III & 1 & 1 & 1 & 1 & 1 & 1 & 1 & 1 & 1 & 1 & 1 & 1 & 1 & 1 & 1 & 2 & 3 & 1 & 1 & 1 & 1 \\
\hline 52 & III & 1 & 2 & 1 & 1 & 1 & 1 & 1 & 1 & 1 & 1 & 1 & 1 & 1 & 1 & 1 & 1 & 1 & 1 & 2 & 1 & 1 \\
\hline $52 \mathrm{a}$ & III & 1 & 2 & 1 & 1 & 1 & 1 & 1 & 1 & 1 & 1 & 1 & & 1 & 1 & 1 & 1 & 1 & 1 & 2 & 1 & 1 \\
\hline $52 \mathrm{~b}$ & III & 1 & 2 & 1 & 1 & 1 & 1 & 1 & 1 & 1 & 1 & 1 & 1 & 1 & 1 & 1 & 1 & & 1 & 2 & 1 & 1 \\
\hline $52 \mathrm{c}$ & III & 1 & 2 & 1 & 1 & 1 & 1 & 1 & 1 & 1 & 1 & & & & 1 & 1 & 1 & 1 & 1 & 2 & 1 & 1 \\
\hline 35 & III & 1 & 2 & 1 & 1 & 1 & 1 & 1 & 1 & 1 & 1 & . & & & 1 & 3 & 1 & 1 & 1 & 2 & 1 & 1 \\
\hline 77 & III & 1 & 3 & 1 & 1 & 1 & 1 & 1 & 1 & 1 & 1 & 1 & 1 & 1 & 1 & 1 & 1 & 1 & 1 & . & 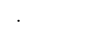 & . \\
\hline 32 & III & 1 & 1 & 1 & 1 & 1 & 2 & 1 & 1 & 1 & 1 & 1 & 1 & 1 & 2 & 3 & 1 & 1 & 1 & 1 & 1 & 1 \\
\hline 28 & III & 1 & 1 & 1 & 1 & 1 & 2 & 1 & 1 & 1 & 1 & 1 & 1 & 1 & 1 & 1 & 1 & 1 & 1 & 1 & 1 & 1 \\
\hline 29 & III & 1 & 1 & 1 & 1 & 1 & 2 & 1 & 1 & 1 & 1 & 1 & 1 & 1 & 1 & 1 & 1 & 1 & 1 & 2 & 1 & 1 \\
\hline 30 & III & 1 & 1 & 1 & 1 & 1 & 2 & 1 & 1 & 1 & 1 & 1 & 1 & 1 & 1 & 3 & 1 & 1 & 1 & 1 & 1 & 2 \\
\hline 23 & III & 1 & 1 & 1 & 1 & 1 & 1 & 1 & 1 & 1 & 1 & 3 & 1 & 0 & 1 & 1 & 1 & . & & 1 & 1 & 1 \\
\hline 24 & III & 1 & 1 & 1 & 1 & 1 & 1 & 1 & 1 & 1 & 1 & 3 & 1 & 0 & 1 & 1 & 1 & & . & 2 & 1 & 1 \\
\hline 6 & III & 1 & 1 & 1 & 1 & 1 & 1 & 1 & 1 & 1 & 1 & 1 & 1 & 1 & 1 & 1 & 1 & 1 & 8 & 1 & 1 & 1 \\
\hline 5 & IV & 1 & 1 & 1 & 1 & 1 & 1 & 1 & 1 & 1 & 1 & 1 & 1 & 1 & 1 & 1 & 1 & & & 3 & 1 & 1 \\
\hline 13 & IV & 1 & 1 & 1 & 1 & 1 & 1 & 1 & 1 & 1 & 1 & 1 & 1 & 1 & 1 & 2 & 1 & & . & 1 & 1 & 1 \\
\hline 20 & IV & 1 & 1 & 1 & 1 & 1 & 1 & 1 & 1 & 1 & 1 & 1 & 1 & 1 & 3 & 3 & 1 & & & 1 & 1 & 1 \\
\hline 22 & IV & 1 & 1 & 1 & 1 & 1 & 1 & 1 & 1 & 1 & 1 & 1 & 4 & 4 & 1 & 1 & 1 & & . & 1 & 1 & 1 \\
\hline 25 & IV & 1 & 1 & 1 & 1 & 1 & 1 & 1 & 1 & 1 & 1 & 3 & 1 & 0 & 3 & 3 & 1 & & . & 1 & 1 & 1 \\
\hline 7 & IV & 1 & 1 & 1 & 1 & 1 & 1 & 1 & 1 & 1 & 1 & 1 & 1 & 1 & 1 & 1 & 1 & 2 & 2 & . & & . \\
\hline $7 \mathrm{a}$ & IV & 1 & 1 & 1 & 1 & 1 & 1 & 1 & 1 & 1 & 1 & 1 & 1 & 1 & 1 & & 1 & 2 & 2 & 1 & 1 & 2 \\
\hline 33 & IV & 1 & 1 & 1 & 1 & 1 & 3 & 1 & 1 & 1 & 1 & 1 & 1 & 1 & 1 & . & 1 & 2 & 2 & 1 & 1 & 2 \\
\hline 8 & IV & 1 & 1 & 1 & 1 & 1 & 1 & 1 & 1 & 1 & 1 & 1 & 1 & 1 & 1 & 1 & 1 & 2 & 3 & 1 & 1 & 1 \\
\hline $8 a$ & IV & & 1 & 1 & 1 & 1 & 1 & 1 & 1 & 1 & 1 & 1 & 1 & 1 & 1 & 1 & 1 & 2 & 3 & & & \\
\hline 9 & IV & 1 & 1 & 1 & 1 & 1 & 1 & 1 & 1 & 1 & 1 & 1 & 1 & 1 & 1 & 1 & 1 & 2 & 3 & 1 & 1 & 2 \\
\hline 12 & IV & 1 & 1 & 1 & 1 & 1 & 1 & 1 & 1 & 1 & 1 & 1 & 1 & 1 & 1 & 1 & 3 & 2 & 3 & & . & . \\
\hline 14 & IV & 1 & 1 & 1 & 1 & 1 & 1 & 1 & 1 & 1 & 1 & 1 & 1 & 1 & 1 & 3 & 1 & 2 & 3 & 1 & 1 & 1 \\
\hline $14 a$ & IV & & 1 & 1 & 1 & 1 & 1 & 1 & 1 & 1 & 1 & 1 & 1 & 1 & 1 & & 1 & 2 & 3 & 1 & 1 & 1 \\
\hline 15 & IV & 1 & 1 & 1 & 1 & 1 & 1 & 1 & 1 & 1 & 1 & 1 & 1 & 1 & 1 & & 1 & 2 & 3 & 1 & 1 & 2 \\
\hline 18 & IV & 1 & 1 & 1 & 1 & 1 & 1 & 1 & 1 & 1 & 1 & 1 & 1 & 1 & 1 & & 2 & 2 & 3 & 1 & 1 & 2 \\
\hline 19 & IV & 1 & 1 & 1 & 1 & 1 & 1 & 1 & 1 & 1 & 1 & 1 & 1 & 1 & 2 & 3 & 1 & 2 & 3 & & & \\
\hline 21 & IV & 1 & 1 & 1 & 1 & 1 & 1 & 1 & 1 & 1 & 1 & 1 & 1 & 3 & 1 & 3 & 1 & 2 & 3 & . & . & . \\
\hline 27 & IV & 1 & 1 & 1 & 1 & 1 & 1 & 1 & 1 & 5 & 1 & 1 & 1 & 1 & 1 & . & 1 & 2 & 3 & 1 & 1 & 1 \\
\hline 31 & IV & 1 & 1 & 1 & 1 & 1 & 2 & 1 & 1 & 1 & 1 & 1 & 1 & 1 & 1 & 3 & 1 & 2 & 3 & 1 & 1 & 2 \\
\hline 34 & IV & 1 & 1 & 2 & 3 & 2 & 1 & 1 & 1 & 1 & 1 & 1 & 1 & 1 & 1 & . & 1 & 2 & 3 & 1 & 1 & 1 \\
\hline
\end{tabular}




$\begin{array}{rll}36 & \text { IV } & 1 \\ 37 & \text { IV } & 1 \\ 38 & \text { IV } & 1 \\ 47 & \text { IV } & 1 \\ 51 & \text { IV } & 1 \\ 51 \mathrm{a} & \text { IV } & 1 \\ 51 \mathrm{~b} & \text { IV } & 1 \\ 51 \mathrm{c} & \text { IV } & 1 \\ 54 & \text { IV } & 1 \\ 39 & \text { IV } & 1 \\ 55 & \text { IV } & 1 \\ 40 & \text { IV } & 1 \\ 40 \mathrm{a} & \text { IV } & 1 \\ 40 \mathrm{~b} & \text { IV } & 1 \\ 41 & \text { IV } & 1 \\ 42 & \text { IV } & 1 \\ 48 & \text { IV } & 1 \\ 49 & \text { IV } & 1 \\ 50 & \text { IV } & 1 \\ 53 & \text { IV } & 1 \\ 53 \mathrm{a} & \text { IV } & 1 \\ 53 \mathrm{~b} & \text { IV } & 1 \\ 53 \mathrm{c} & \text { IV } & 1 \\ 53 \mathrm{~d} & \text { IV } & 1 \\ 53 \mathrm{e} & \text { IV } & 1 \\ 56 & \text { IV } & 1 \\ 57 & \text { IV } & 1 \\ 58 & \text { IV } & 1 \\ 59 & \text { IV } & 1 \\ 60 & \text { IV } & 1 \\ 61 & \text { IV } & 1 \\ 62 & \text { IV } & 1 \\ 63 & \text { IV } & 1 \\ 64 & \text { IV } & 1 \\ 65 & \text { IV } & 1 \\ 66 & \text { IV } & 1 \\ 69 & \text { IV } & 1 \\ 70 & \text { IV } & 1 \\ 73 & \text { IV } & 1 \\ 74 & \text { IV } & 1 \\ 75 & \text { IV } & 1 \\ 76 & \text { IV } & 1 \\ 43 & \text { IV } & 1 \\ 44 & \text { IV } & 1 \\ 67 & \text { IV } & 1 \\ 71 & \text { IV } & 1 \\ 72 & \text { IV } & 1 \\ 45 & \text { IV } & 1 \\ 46 & \text { IV } & 1 \\ 68 & \text { IV } & 1 \\ 83 & \text { IV } & 3 \\ 78 & \text { IV } & 2 \\ 82 & \text { IV } & 2 \\ 90 & \text { IV } & 4 \\ 79 & \text { II } & 2 \\ 80 & \text { II } & 2 \\ 81 & \text { II } & 2 \\ & & \end{array}$




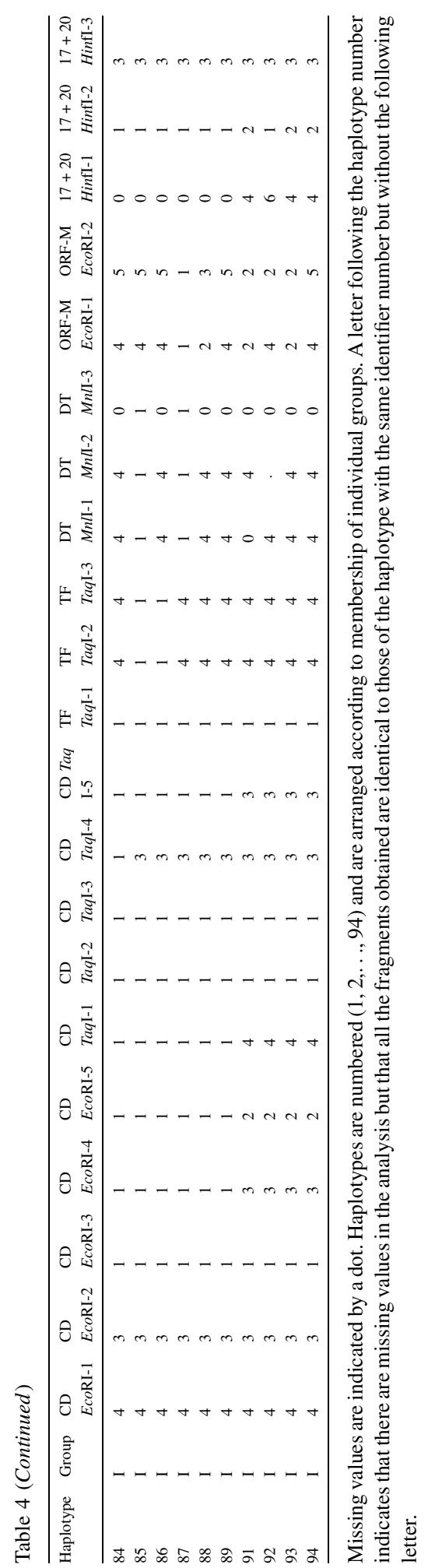

The most common haplotype was haplotype 2, which belonged to Group III. This was by far the most common haplotype in the whole survey and was represented by 284 (46\%) of the 615 non-hybrid samples that were analysed. It was abundant in Italy, Austria, Germany, Netherlands, Belgium and Britain whereas it was extremely rare in Spain and France and entirely absent from Hungary (Fig. 2a). It is impossible to know whether the samples from Italy truly belong to haplotype 2 as they have data missing at locus ORF-M so caution is needed in interpreting the presence and distribution of haplotype 2 in Italy. Haplotypes 35 and 52, which were borderline between Groups III and IV were restricted to the Netherlands. The other haplotypes which belonged to Group III (haplotypes 1, 3, 4, 6, 10, 11, 16, 17, 23, $24,26,28,29,30,32$ and 77) had an almost entirely eastern distribution. An area along the Danube in northeastern Austria was particularly rich in diversity with eight haplotypes from Group III growing within a very small area (Fig. 2a). The majority of samples from Hungary belonged to haplotype 10 and this haplotype was restricted to Hungary with the sole exception of one sample from Austria. If haplotype 2 and 52 are excluded, haplotypes, which belonged to Group III, only occurred in seven samples outside Italy, Austria and Hungary (Fig. 2a).

Spain had the highest diversity with a total of 45 haplotypes of which 38 were unique to Spain. Of the remaining seven haplotypes only one (haplotype 2) occurred further east than the Netherlands and two (haplotypes 7 and 58) were restricted to France and Spain. Haplotypes 14 and 53 were common haplotypes, which occurred both within and beyond Spain. The 40 samples that were haplotype 14 were found in Spain, France and Germany and the 50 samples of haplotype 53 occurred in Spain, France, the Netherlands and Britain.

Italy also showed quite a high diversity with nine haplotypes of which six were unique to Italy. The countries with the lowest diversity were Hungary with three haplotypes and Britain with three haplotypes.

In Britain and the Netherlands, which are at the northwestern limit of the species, haplotypes from Groups III and IV grew in close proximity to one another (Fig. 2). 


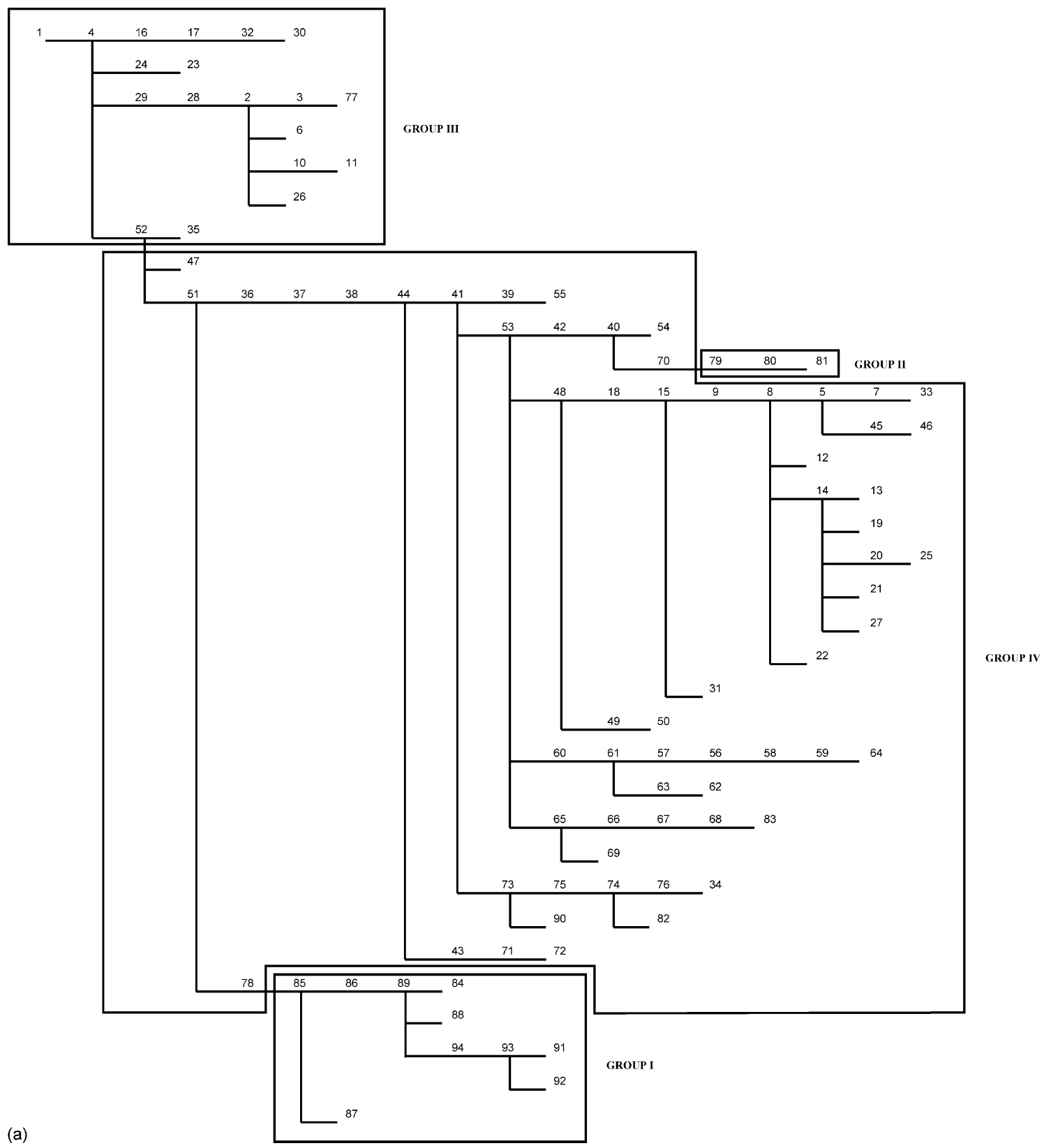

Fig. 1. (a) The minimum spanning tree for 94 hybrid and non-hybrid $P$. nigra genebank samples based on the molecular data presented in Table 4. The division of the individual haplotypes into Groups I-IV is shown. (b) The phylogenetic tree of 94 hybrid and non-hybrid P. nigra genebank samples obtained by the Fitch algorithm. The molecular data for each numbered haplotype are presented in Table 4 . The large circles encompass Group I and II haplotypes. The uncircled numbers indicate haplotypes, which belong to Group III, and circles around single or, in rare cases, two haplotypes indicate membership of Group IV. 


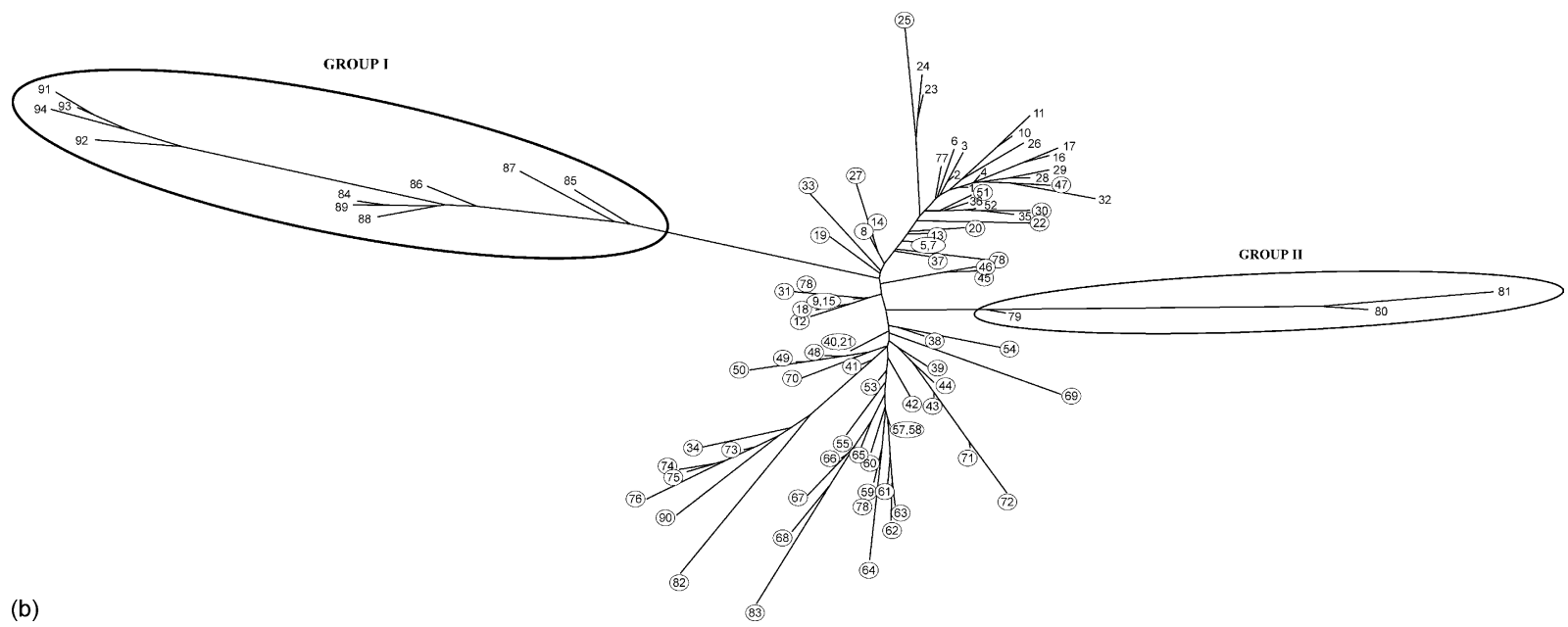

Fig. 1. (Continued).

\section{Discussion}

\subsection{Postglacial refugia and routes of colonisation}

The phylogenetic analyses of all the European genebank samples clearly divided the non-hybrid haplotypes, which had a western distribution from those located in the east (Fig. 3). The Italian group was located between the eastern and the western samples. Haplotypes from the west were more similar to each other than to those found in the east and vice versa. This, along with the fact that Spain in the southwest and Austria and Italy in the southeast had high diversity, suggest that there were refugia of black poplar in both southwestern and southeastern Europe. The Iberian Peninsula is considered to have been a glacial refugium for other tree species such as Quercus (Jimenez et al., 1999; Goicoechea and Agúndez, 2000) and Pinus (Salvador et al., 2000) and Alba et al. (2002) suggested, on the basis of the high diversity detected in black poplar in Spain, that this may have acted as a refuge for $P$. nigra. The current analysis provides further evidence to support the idea that western refugia existed in Spain. The results indicate that the Pyrenees acted as an effective barrier to migration because only 6 of the 44 non-hybrid haplotypes detected in Spain existed elsewhere in Europe. The exact number and locations of Spanish refugia remains unclear. In an analysis of the Spanish results Alba et al.
(2002) commented that the cpDNA diversity in the Ebro valley was much higher than in the Douro and Tagus valleys. The comparison of black poplar populations on these three rivers showed that 41 of the 45 haplotypes found were unique to the Ebro valley (Alba et al., 2002). The Ebro valley runs parallel to the Pyrenees in eastern Spain and eventually flows into the Mediterranean. In contrast, the other two rivers flow in a westerly direction across Spain and eventually into the Atlantic. The higher diversity in the Ebro valley may indicate that this area included some of the more important glacial refugia of the species. Uncertainty regarding the exact location of Iberian refugia also exists in other tree species. For example, palynological evidence led Brewer et al. (2002) to propose that the Spanish refugia for oak were restricted to the extreme south of the country. However, Olande et al. (2002) point out that in Iberia, altitude and topography override the latitudinal effects on climate, bringing moisture to southern regions and mild temperatures to northern ones. Vegetation could have survived the glacial period in basal mountain valleys and deep gorges outside southern Iberia. They quote evidence to support the idea that other species, such as Corylus (Sánchez Goñi and Hannon, 1999), may have survived in refugia located in deep gorges in the river Ebro basin. The results, therefore, highlight the need to perform a more structured sampling of Spain, perhaps for a number of tree species, if the 

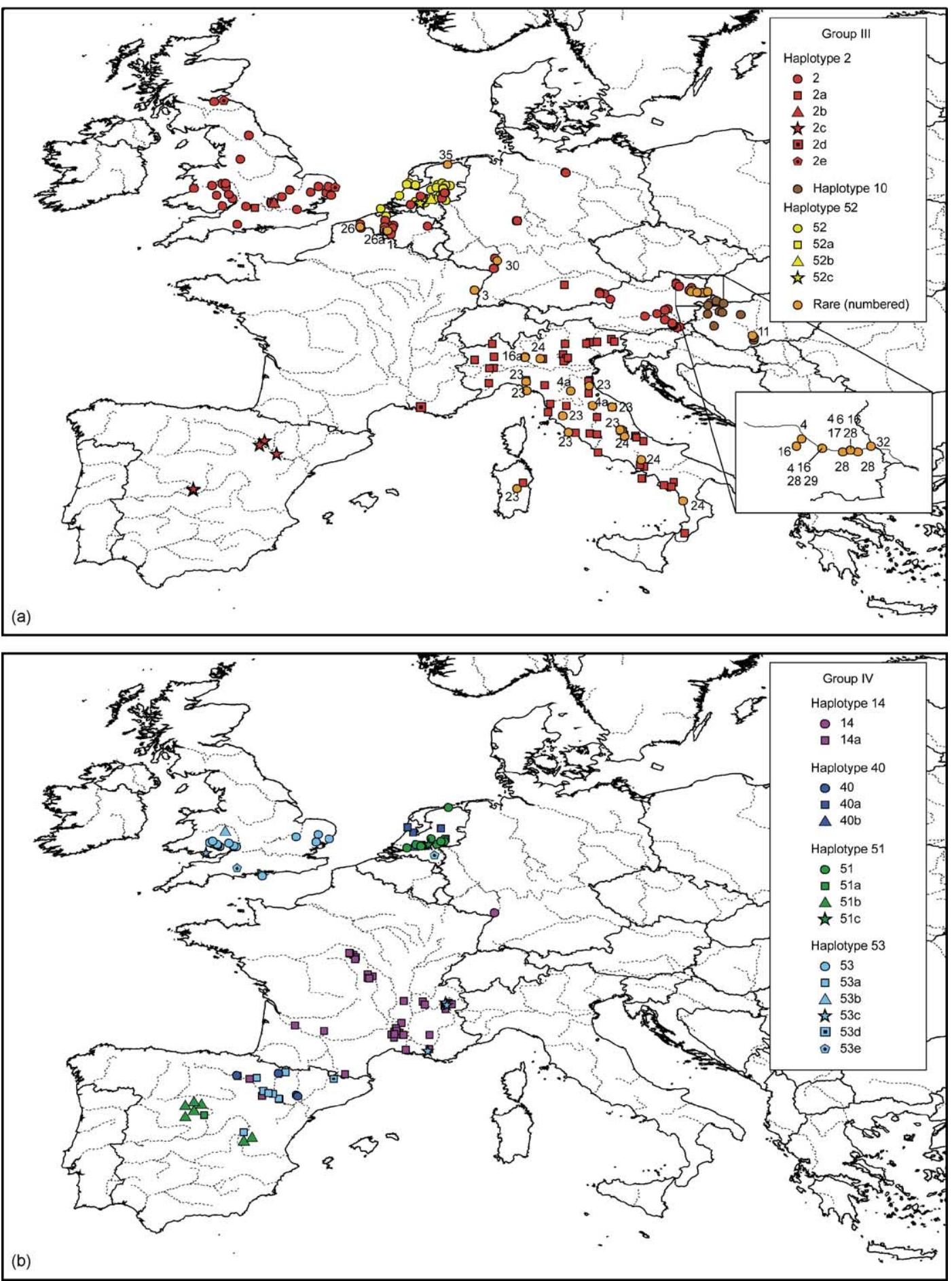

Fig. 2. (a-d) Maps showing the distribution of haplotypes of non-hybrid P. nigra genebank samples. Key: Map (a), Group III (the exact location of haplotype 77 in France is unknown); Maps (b, c and d) Group IV (the exact location of haplotype 78 is unknown). Common haplotypes are allocated a unique colour whereas haplotypes, which are rare, are presented with their haplotype number alongside their location on each map. 

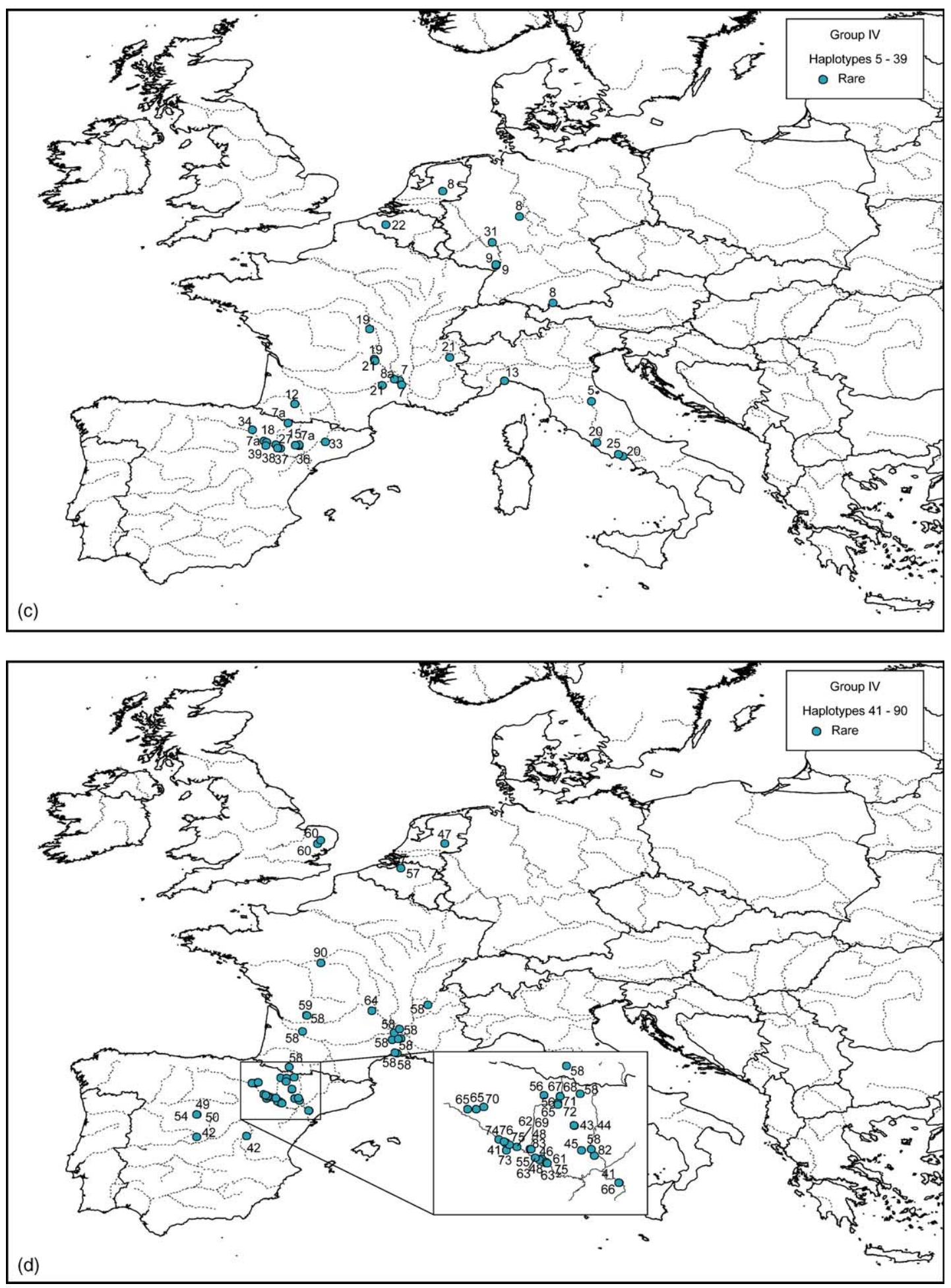

Fig. 2. (Continued). 
Table 5

The effect of latitude on the number of haplotypes present. The exact location of haplotype 91 in Hungary is unknown

\begin{tabular}{llr}
\hline Latitude & Identity and total number of non-hybrid haplotypes \\
\hline$<42^{\circ} \mathrm{N}$ & $11,15,18,20,23,24,25,27,33,36,37,38,39,40,41$, & 41 \\
& $42,45,46,48,49,50,54,55,58,61,62,63,66,69$, \\
$42-44^{\circ} \mathrm{N}$ & $73,74,75,76,82,83,14 \mathrm{a}, 2 \mathrm{a}, 51 \mathrm{a}, 53 \mathrm{a}, 7 \mathrm{a}$ & 21 \\
$44-46^{\circ} \mathrm{N}$ & $5,12,23,24,34,40,43,44,56,58,65,67,68,70,71,72,14 \mathrm{a}, 2 \mathrm{a}, 53 \mathrm{a}, 7 \mathrm{a}$ & 14 \\
$46-48^{\circ} \mathrm{N}$ & $7,13,19,21,23,24,58,59,64,14 \mathrm{a}, 16 \mathrm{a}, 2 \mathrm{a}, 53 \mathrm{c}, 8 \mathrm{a}$ & 7 \\
$48-50^{\circ} \mathrm{N}$ & $2,8,10,19,81,14 \mathrm{a}, 2 \mathrm{a}$ & 13 \\
$50-52^{\circ} \mathrm{N}$ & $2,3,6,9,10,14,16,17,28,29,30,32$ \\
$>52^{\circ} \mathrm{N}$ & $1,2,8,22,26,31,51,52,53,57,40$ & 11 \\
\hline
\end{tabular}

exact locations of the refugia are to be identified. Such a survey would identify the regions of greatest diversity, which merit the most effort in terms of conservation.

The exact locations of the eastern refugia are also difficult to identify accurately. The Italian peninsula contained many unique haplotypes and this lends support to the idea that this area acted as a refugium. The Alps appear to have acted as a barrier to the escape of most of the Italian haplotypes. There were also several unique haplotypes in eastern Austria and Hungary so the data also support the idea of a refugium somewhere to the east of Italy. The high diversity detected by Bordács et al. (2002a) in a population growing along the Danube River in Hungary is further support for this. It will be necessary to obtain additional material from locations south and east of Hungary to confirm the existence and location of this putative refugium. The presence of haplotype 2 throughout Italy and also in Austria but almost entirely absent from France is interesting. This pattern of distribution suggests that the Alps formed a very effective barrier to the movement of this haplotype into France but appeared to allow migration into Austria. Alternatively, this haplotype may have existed in more than one refugium, possibly in Italy and also in an area east of the Adriatic Sea in the Balkan region. The Balkan material could then have migrated northwards to colonise Austria without having to cross any major mountain ranges. A similar situation was found for an oak haplotype which occurs in both southern Italy and the Balkans (Bordács et al., 2002b; Csaikl et al., 2002; Fineschi et al., 2002; Petit et al., 2002b). They suggested that the presence of a haplotype in both these refugial areas may have resulted from its migration across the Adriatic Sea in a

Table 6

The presence of non-hybrid haplotypes in each country

\begin{tabular}{|c|c|c|c|c|c|c|c|c|c|c|c|c|c|c|c|}
\hline \multirow[t]{3}{*}{ Country } & \multirow{3}{*}{$\begin{array}{l}\text { Number of non- } \\
\text { hybrid haplotypes }\end{array}$} & \multicolumn{14}{|c|}{ Non-hybrid haplotype composition according to country and Group } \\
\hline & & \multirow[t]{2}{*}{ Group II } & \multicolumn{5}{|c|}{ Group III } & \multicolumn{8}{|c|}{ Group IV } \\
\hline & & & 2 & 4 & 10 & 16 & $\bar{U}$ & 53 & 7 & 8 & 14 & 58 & 40 & 51 & $\mathrm{U}$ \\
\hline Austria & 9 & & $\mathrm{X}$ & $\mathrm{X}$ & $\mathrm{X}$ & $\mathrm{X}$ & 5 & & & & & & & & \\
\hline Belgium & 5 & & $\mathrm{X}$ & & & & 2 & & & & & & & & 2 \\
\hline Hungary & 3 & 1 & & & $\mathrm{X}$ & & 1 & & & & & & & & \\
\hline Italy & 9 & & $\mathrm{X}$ & $\mathrm{X}$ & & $X$ & 2 & & & & & & & & 4 \\
\hline Britain & 3 & & $\mathrm{X}$ & & & & & $\mathrm{X}$ & & & & & & & 1 \\
\hline Germany & 10 & 2 & $\mathrm{X}$ & & & & 2 & & & $\mathrm{X}$ & $\mathrm{X}$ & & & & 3 \\
\hline France & 12 & & $\mathrm{X}$ & & & & 1 & $\mathrm{X}$ & $X$ & $\mathrm{X}$ & $\mathrm{X}$ & $\mathrm{X}$ & & & 5 \\
\hline Netherlands & 7 & & $\mathrm{X}$ & & & & 2 & $\mathrm{X}$ & & & & & $\mathrm{X}$ & $\mathrm{X}$ & 1 \\
\hline Spain & 45 & & $\mathrm{X}$ & & & & & $\mathrm{X}$ & $\mathrm{X}$ & & $\mathrm{X}$ & $\mathrm{X}$ & $\mathrm{X}$ & $\mathrm{X}$ & 38 \\
\hline
\end{tabular}

The presence of a haplotype is represented by $\mathrm{X}$ and the number of haplotypes which are unique to a given country are listed in the column labelled U. The total number of non-hybrids per country per group are presented. 


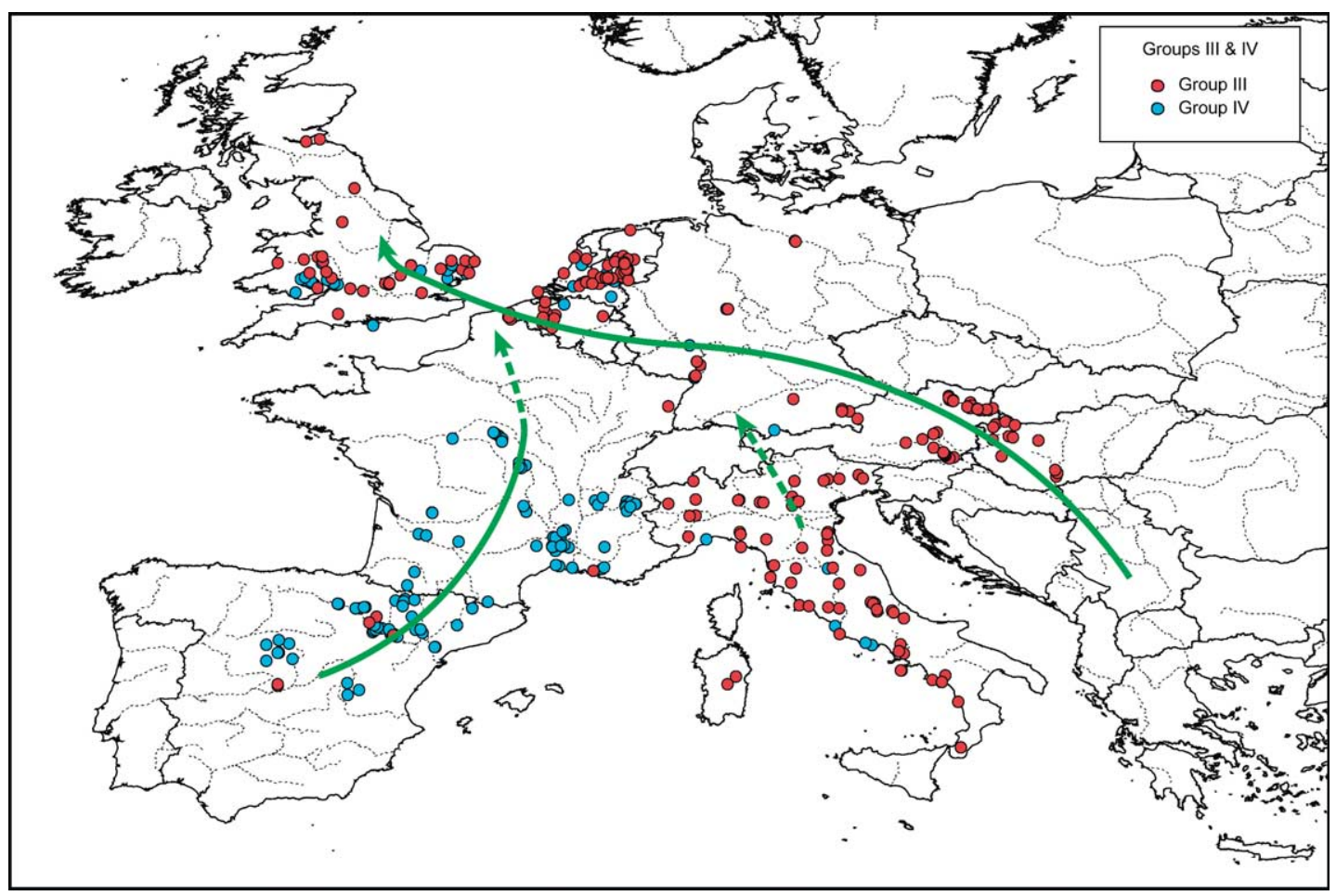

Fig. 3. Summary map showing distribution of haplotypes from Groups III and IV and suggested routes of colonisation.

previous interglacial period. This would have been possible because of the land bridge, which existed at this time.

The phylogenetic analysis showed that three haplotypes (79, 80 and 81), which constituted Group II, were very different from the other haplotypes that were detected in the study. Bordács et al. (2002a) found that some of the Hungarian samples, which had a similar cpDNA fingerprint to these samples, produced the banding pattern typical of the 'Thevestina' clone when analysed using the Heinze (1998a,b) cpDNA marker. Haplotypes 79, 80 and 81 might therefore be distinct because they originate from the same area as 'Thevestina', which itself originates from the Central Asian and Black Sea region and has been widely used as an ornamental tree. This highlights the need to extend the sampling to regions further east.

The hypothesis that there were at least three refugia for black poplar is consistent with findings for other tree species (Taberlet et al., 1998). For example, in oak, refugia in Spain, Italy and the Balkans have been proposed (Dumolin-Lapègue et al., 1997; Ferris et al.,
1998; Petit et al., 2002b). The three refugia are all thought to have provided material for postglacial colonisation of countries to the north. In contrast, beech and alder, share a refuge in the Carpathian region from whence most of Europe was recolonised. Both species also have unique haplotypes in southern Italy, which apparently did not spread across the Alps.

The higher levels of cpDNA diversities in the southern compared to the northern populations found in $P$. nigra agree with previous phylogeographic results in other tree species such as Fagus, Quercus and Alnus (Démesure et al., 1996; Dumolin-Lapègue et al., 1997; King and Ferris, 1998). For example, twelve of the thirteen alder haplotypes detected by King and Ferris (1998) occur south of $45^{\circ} \mathrm{N}$ latitude. Similarly in oak, of the 32 haplotypes that were detected 12 were restricted to regions below $45^{\circ} \mathrm{N}, 3$ occurred only above $45^{\circ} \mathrm{N}$ and 17 occurred in both northern and southern regions (Petit et al., 2002a). This is also true of $P$. nigra in which 50 of the 83 nonhybrid haplotypes are restricted to latitudes below $46^{\circ} \mathrm{N}$. Two possible reasons for this thinning of 
haplotypes from south to north have been suggested in the literature. Firstly, the large mountain ranges such as the Pyrenees, Alps and Carpathian mountains are all in Southern Europe and these may have acted as barriers preventing the majority of haplotypes from migrating northwards during postglacial recolonisation. Secondly, this reduction in diversity during expansion from refugia has been predicted for species that undergo leptokurtic (long distance) as opposed to normal dispersal (Hewitt, 1996).

In her initial survey of cpDNA variation in the EUFORGEN Core Collection (based on a complete data from the seven loci used in the current study), Krystufek (2001) found that haplotype 2 occurred in all the countries tested in the Europop project except for France and Spain. This haplotype was also present in samples from as far east as Romania and the Ukraine. The great abundance of haplotype 2 may be a reflection of both the difficulty that black poplar experienced in escaping the refugia after the ice age and the subsequent rapid rates of colonisation. The viability of black poplar seeds is known to be extremely short lived and it has very exacting germination requirements found only along river valleys, which are flooded in winter (Barsoum and Hughes, 1998). Indeed, Imbert and Lefèvre (2003) deduced from the isolation by distance pattern of the distribution of diversity within a single river system that seed dispersal in black poplar is not effective over a very long distance. This may have made it difficult for the haplotypes that had escaped across the mountain ranges to find land immediately beyond which was suitable for germination. The fact that black poplar readily propagates vegetatively may have assisted it to migrate across mountain barriers. The occasional transport of twigs over long distances by water, birds, beavers or man may have played an important role in the expansion of the species from refugia. Haplotype 2 may have been the first to escape over the physical mountain barriers to establish founding populations beyond. The seed produced by these first generation trees would have had the opportunity to be spread rapidly by wind across the flat plains of Europe in the absence of other haplotypes. Although there are no palynological data for black poplar, data for other wind or water dispersed species such as Betula, Pinus and Alnus indicate rapid colonisation rates of 500-2000 $\mathrm{m}$ year $^{-1}$ (Huntley and
Birks, 1983). Other species such as oaks, which rely on birds for dispersal, spread at a slower rate of 350500 m year $^{-1}$.

Despite the fact that haplotype 2 predominated, there was relatively high diversity of cpDNA haplotypes in northern Europe. Presumably, many of the haplotypes, which escaped across the physical mountain barriers, successfully migrated northwards, albeit in lower density than haplotype 2 . This pattern is quite different from that of oak, where no unique haplotypes are found in northwestern Europe (Ibrahim et al., 1996). For species such as oak, the hypothesis is that rare, long distant dispersal events allowed single haplotypes to colonise large areas. Once these large, single haplotype areas were established it was impossible for other haplotypes to gain a foothold because appropriate sites had already been colonised. This led to a loss of diversity as the species moved northwards. The ecology of black poplar is very different from that of oak in several ways and this may account for the different distribution patterns of the haplotypes. First, oak is a climax species whereas black poplar is a non-climax pioneering species, which colonises disturbed riverine sites. As a consequence, black poplar tends to have a patchy distribution of populations concentrated along linear river valleys. Secondly, the black poplar populations are in a much more dynamic state than those of the oaks, they are constantly being re-established due to changing river dynamics as old sites with mature trees are lost and new ones are founded from immigrant seed. As a result, new colonisation sites are constantly being made available behind the initial colonisation front. Thirdly, the size of the catchment area for recruited seeds and vegetative propagules may be relatively large. As a result the following scenario can be envisaged. Haplotypes, which arrive after the first colonisation front, can establish themselves as new sites become available when rivers flood and change their courses. They, therefore, form small populations dotted in among populations of the original colonising haplotype. These small populations form steppingstones to the northerly progression of the haplotypes, which are later in arriving. Some of these steppingstones are lost when river dynamics change resulting in the ebb and flow of loss and establishment of populations. The dynamic renewal of colonisation sites would also explain why haplotypes from both 
eastern and western refugia coexist in Britain. One of the lineages will have arrived first but this will not have prevented the lineage, which arrived later from colonising, because new sites would constantly have been becoming available. This may also explain why some of the northern populations contain unique haplotypes, which are absent further south. The route taken by some of the P. nigra haplotypes may have been obliterated when populations were lost when rivers changed their course. Alternatively, if the haplotypes are rare, the sampling intensity may just have been too low to enable the route to be traced.

\subsection{Human influence}

The hypothesis outlined above assumes that the observed pattern of cpDNA haplotypes has been established naturally. Movement of material by man and human mediated planting of one of the lineages could be an alternative explanation for the coexistence of eastern and western lineages in Britain. Cottrell et al. (2002) showed that although eastern and western haplotypes were present in Britain in similar numbers the situation was very different in terms of numbers of clones. Britain has a very high degree of clonal duplication (Cottrell et al., 1997, 2002) and there were only three different clones derived from the western lineage compared with twenty separate clones from the eastern lineage. It is therefore possible that the three clones from the western lineage were introduced, propagated and distributed by man. This would mean that Britain had only been naturally colonised by the eastern lineage.

This example illustrates the difficulty in interpreting cpDNA data for black poplar. The fact that it can be vegetatively propagated, coupled with the high level of human interference that the species has experienced, makes it impossible to be certain that the distribution of the various cpDNA haplotypes in Europe today is a true reflection of natural pattern of postglacial colonisation.

One of the other effects of human interference on $P$. nigra in Europe has been the widespread occurrence of $P . \times$ euramericana and other poplar hybrids throughout northern Europe. Artificially produced hybrids involving $P$. nigra and several other poplar species including $P$. deltoides, $P$. trichocarpa, $P$. maximowiczii and $P$. laurifolia have been planted throughout Europe.
Such crosses have been made with $P$. nigra acting as either the male or the female parent. In addition, natural hybridisation and backcrossing of hybrids with black poplar is known to occur. It should be borne in mind that failure to recognise a hybrid or a backcross in which the maternal line is a species other than P. nigra could lead to misinterpretation of the current results for the construction of colonisation routes. The interpretation of the current results assumes that any hybrids that were sampled were detected and removed before consideration of postglacial colonisation routes. This assumption is probably correct because the Fitch analysis positioned all but one of the suspected hybrid haplotypes into a well-defined group of their own. This, coupled with the fact that all the morphology of all the trees included in the genebanks was examined prior to inclusion to check that they were typical of non-hybrid $P$. nigra specimens gives confidence that the postglacial colonisation routes defined in this paper are based on non-hybrid P. nigra trees.

\subsection{Future work}

The current work only sampled countries as far south as Spain and Italy and as far east as Hungary. A large area of the distribution range of black poplar in North Africa, Russia and China remains unsampled. Group II provides an initial suggestion that diversity in Eastern Europe may be very different from that further west. In order to trace the colonisation routes more clearly there is a need for a further sampling effort in the east. Along with a more structured sampling of Spain, this will identify material in the regions where the diversity was highest and which merit the greatest conservation effort. An analysis of the Italian samples at locus ORF-M EcoRI would also clarify the relationship of these trees to those elsewhere in Europe.

\section{Acknowledgements}

This study has been carried out with financial support from the Commission of the European Communities, Agriculture and Fisheries (FAIR) specific RTD programme, PL97-3386, 'Genetic diversity in river populations of European Black 
Poplar for evaluation of biodiversity, conservation strategies, nature development and genetic improvement'. It does not necessarily reflect its views and in no way anticipates the Commission's future policy in this area. The Hungarian studies were financed by a Hungarian governmental grant (OTKA T32404).

We thank Glen Brearley for his expert assistance in the preparation of the figures and maps.

\section{References}

Alba, N., Maestro, D., Agúndez, D., Novitol, E., 2002. Advances in the preservation of genetic resources in Populus nigra L. in Spain. In: van Dam, B.C., Bordács, S. (Eds.), Genetic Diversity in River Populations of European Black Poplar-implications for Riparian Eco-system Management. Proceedings of an International Symposium, Szekzárd, Hungary, May 2001.

Anonymous, 1990. Ministerial Conference Strasbourg. Actes de la Conférence Ministérielle pour la Protection des Forêts en Europe, 18 Décembre 1990. Strasbourg. Ministère de L'Agriculture et des Forêts, France. 255 pp.

Arbez, M., Lefèvre, F., 1997. Towards a European genetic resource programme: objectives and general conception-a case study concerning black poplar (Populus nigra L.). Bocconea 7, 389398.

Barsoum, N., Hughes, F.M.R., 1998. Regeneration response of black poplar to changing river levels. In: Wheater, H., Kirby, C. (Eds.), Hydrology in a Changing Environment. pp. 397412.

Bennett, K.D., 1990. Milankovitch cycles and their effects on species in ecological and evolutionary time. Paleobiology 16, $11-21$.

Bennett, K.D., Tzedakis, P.C., Willis, K.J., 1991. Quaternary refugia of north European trees. J. Biogeography 18, 103-115.

Bordács, S., Borovics, A., Bach, I., 2002a. Genetic diversity of natural populations and genebank of black poplar in Hungary. In: van Dam, B.C., Bordács, S. (Eds.), Genetic Diversity in River Populations of European Black Poplar-implications for Riparian Eco-system Management. Proceedings of an International Symposium, Szekzárd, Hungary, May 2001.

Bordács, S., Popescu, F., Slade, D., Csaikl, U.M., Lesur, I., Borovics, A., Kézdy, P., König, A.O., Gömöry, D., Brewer, S., Burg, K., Petit, R.J., 2002b. Chloroplast DNA variation of white oaks in northern Balkans and in the Carpathian Basin. For. Ecol. Manag. 156, 197-210.

Brewer, S., Cheddadi, R., de Beaulieu, J.L., Reille, M., 2002. The spread of deciduous Quercus throughout Europe since the last glacial period. For. Ecol. Manag. 156, 27-48.

Cottrell, J.E., Forrest, G.I., White, I.M.S., 1997. The use of RAPD analysis to study diversity in British black poplar (Populus nigra L. subsp. betulifolia (Pursch) W. Wettst. (Salicaceae)) in Great Britain. Watsonia 21, 305-312.

Cottrell, J.E., Tabbener, H.E., Forrest, G.I., 2002. Distribution of variation in British black poplar: role for human management.
In: van Dam, B.C., Bordács, S. (Eds.), Genetic Diversity in River Populations of European Black Poplar-implications for Riparian Eco-system Management. Proceedings of an International Symposium, Szekzárd, Hungary, May 2001.

Csaikl, U.M., Burg, K., Fineschi, S., König, A.O., Mátyás, G., Petit, R.J., 2002. Chloroplast DNA variation in white oaks in the alpine region. For. Ecol. Manag. 156, 131-147.

Démesure, B., Sodzi, N., Petit, R.J., 1995. A set of universal primers for amplification of polymorphic non-coding regions of mitochondrial and chloroplast DNA in plants. Mol. Ecol. 4, 129-131.

Démesure, B., Comps, B., Petit, R., 1996. Phylogeography of common beech (Fagus sylvatica L.) in Europe inferred by restriction studies of PCR amplified chloroplast DNA fragments. Evolution 50, 2515-2520.

Dumolin-Lapègue, S., Démesure, B., Fineschi, S., Le Corre, V., Petit, R., 1997. Phylogeographic structure of white oaks throughout the European continent. Genetics 146, 1475-1487.

El Mousadik, A., Petit, R.J., 1996. Chloroplast DNA phylogeography of the argan tree of Morocco. Mol. Ecol. 5, 547-555.

Felsenstein, J., 1993. PHYLIP (Phylogeny Inference Package) Version 3.5c. Department of Genetics, University of Washington, Seattle, WA.

Ferris, C., King, R.A., Vainola, R., Hewitt, G.M., 1998. Chloroplast DNA recognises three refugial sources of European oaks and shows independent eastern and western immigrations to Finland. Heredity 80, 584-593.

Fineschi, S., Taurchini, D., Grossini, P., Petit, R.J., Vendramin, G.G., 2002. Chloroplast DNA variation in Italy. For. Ecol. Manag. 156, 103-114.

Fluch, S., Krystufek, V., Burg, K., 2002. A chloroplast marker system for studying genetic variation in P. nigra. In: van Dam, B.C., Bordács, S. (Eds.), Genetic Diversity in River Populations of European Black Poplar-implications for Riparian Eco-system Management. Proceedings of an International Symposium, Szekzárd, Hungary, May 2001.

Goicoechea, P.G., Agúndez, D., 2000. Robles y Hayas en Espańa. Conservación de Recursos Genéticos. Investigación Agararia: Sistemas y Recursos Forestales. Fuera de Serie 2, 125-142.

Heinze, B., 1997. A PCR marker for a Populus deltoides allele and its use in studying introgression with native European Populus nigra. Belg. J. Bot. 129, 123-130.

Heinze, B., 1998a. PCR-based chloroplast DNA assays for the identification of native Populus nigra and introduced poplar hybrids in Europe. For. Genet. 5, 31-38.

Heinze, B., 1998b. Biochemical and molecular genetic methods available for the characterization of Populus nigra L. In: Turok, J., Lefèvre, F., de Vries, S., Alba, N., Heinze, B., Van Slycken, J. (Compilers), Populus nigra Network. Report of the fourth meeting, 3-5 October 1997, Geraardsbergen, Belgium. International Plant Genetic Resources Institute, Rome.

Hewitt, G.M., 1996. Some genetic consequences of ice ages, and their role in divergence and speciation. Biol. J. Linn. Soc. 58, 247-276.

Huntley, B., Birks, H.J.B., 1983. An Atlas of Past and Present Pollen Maps of Europe, 0-13,000 Years Ago. Cambridge University Press, Cambridge. 
Ibrahim, K.M., Nichols, R.A., Hewitt, G.M., 1996. Spatial patterns of genetic variation generated by different forms of dispersal during range expansion. Heredity 77, 282-291.

Imbert, E., Lefèvre, F., 2003. Dispersal and gene flow of Populus nigra (Salicaceae) along a dynamic river system. J. Ecol. 91, 447-456.

Jimenez, P., Agundez, D., Alis, D., Gil, L., 1999. Genetic variation in Central and Marginal population of Quercus suber L. Silv. Genet. 48 (6), 278-284.

King, R., Ferris, C., 1998. Chloroplast DNA phylogeography of Alnus glutinosa. Mol. Ecol. 7, 1151-1161.

Krystufek, V., 2001. Population genetic analysis of Populus nigra in Austria using nuclear and Chloroplast DNA markers, Ph.D. Thesis, University of Vienna, pp. 47-52.

Krystufek, V., Fluch, S., Burg, K., 2002. Artificial yet natural: colonisation by black poplar of an artificial island in the river Danube in Vienna. In: van Dam, B.C., Bordács, S. (Eds.), Genetic Diversity in River Populations of European Black Poplar-implications for Riparian Eco-system Management. Proceedings of an International Symposium, Szekzárd, Hungary, May 2001.

Lagercrantz, U., Putterill, J., Coupland, G., Lydiate, D., 1997. Comparative mapping in Arabidopsis and Brassica: fine scale genome colinearity and congruence of genes. Plant J. 9, 13-20.

Lefèvre, F., Legionnet, A., de Vries, S., Turok, J., 1998. Strategies for conservation of a pioneer tree species, Populus nigra L., in Europe. Genet. Sel. Evol. 30 (Suppl. 1), 181-196.

Mejnartowicz, M., 1991. Inheritance of chloroplast DNA in Populus. Theor. Appl. Genet. 82, 477-480.

Olande, M., Herrán, A., Espinel, S., Goicoechea, P.G., 2002. White oaks phylogeography in the Iberian Peninsula. For. Ecol. Manag. 156, 89-102.

Payne, R.W., Lane, P.W., Digby, P.G.N., et al., 1993. Genstat ${ }^{\mathrm{TM}} 5$ Release 3 Reference Manual. Clarendon Press, Oxford.

Petit, R.J., Csaikl, U.M., Bordács, S., Burg, K., Coart, E., Cottrell, J., van Dam, B., Deans, J.D., Dumolin-Lapegue, S., Fineschi, S., Finkeldey, R., Gillies, A., Glaz, I., Goicoechea, P.G., Jensen, J.S., Konig, A.O., Lowe, A.J., Madsen, S.F., Matyas, G., Munro, R.C., Oledska, M., Pemonge, M.-H., Popescu, F., Slade, D., Tabbener, H., Taurchini, D., de Vries, S.G.M., Ziegenhagen, B., Kremer, A., 2002a. Chloroplast DNA variation in European white oaks: phylogeography and patterns of diversity based on data from over 2600 populations. For. Ecol. Manag. 156, $5-26$.

Petit, R.J., Brewer, S., Bordács, S., Burg, K., Cheddadi, R., Coart, E., Cottrell, J., Csaikl, U.M., van Dam, B., Deans, J.D., Espinel, S., Fineschi, S., Finkeldey, R., Glaz, I., Goicoechea, P.G., Jensen, J.S., Konig, A.O., Lowe, A.J., Madsen, S.F., Matyas, G., Munro, R.C., Popescu, F., Slade, D., Tabbener, H., de Vries, S.G.M., Ziegenhagen, B., de Beaulieu, J.-L., Kremer, A., 2002b. Identification of refugia and postglacial colonisation routes of European white oaks based on chloroplast DNA and fossil pollen evidence. For. Ecol. Manag. 156, 49-74.

Prim, R.C., 1957. Shortest connection networks and some generalizations. Bell Syst. Tech. J. 36, 1389-1401.

Rajora, O.P., Dancik, B.P., 1992. Chloroplast inheritance in Populus. Theor. Appl. Genet. 84, 280-285.
Rajora, O.P., Dancik, B.P., 1995a. Chloroplast DNA variation in Populus 1. Intraspecific restriction fragment diversity within Populus deltoides, P. nigra and P. maximowiczii. Theor. Appl. Genet. 90, 317-323.

Rajora, O.P., Dancik, B.P., 1995b. Chloroplast DNA variation in Populus 2. Interspecific restriction fragment polymorphisms and genetic relationships among Populus deltoides, P. nigra, $P$. maximowiczii and P. $\times$ canadensis. Theor. Appl. Genet. 90, 324-330.

Rajora, O.P., Dancik, B.P., 1995c. Chloroplast DNA variation in Populus 3. Novel chloroplast variants in natural Рориlus $\times$ canadensis hybrids. Theor. Appl. Genet. 90, 331-334.

Sabsch, M., 1992. Untersuchungen über inter- und intraspezifische variation der cpDNA in der Gattung Populus. Thesis Dissertation, University of Göttingen.

Salvador, L., Alia, R., Agundez, D., Gil, L., 2000. Genetic variation and migration pathways of maritime pine (Pinus pinaster Ait) in the Iberian Peninsula. Theor. Appl. Genet. 100, 89-95.

Samuel, R., Pinsker, W., Kiehn, M., 1997. Phylogeny of some species of Cyrtandra inferred from the atpB/rbc1 cpDNA intergene region. Botanica Acta 110, 503-510.

Smith, R.L., Sytsma, K.J., 1990. Evolution of Populus nigra (Sect. Aigeiros): introgressive hybridization and the chloroplast contribution of Populus alba (Sect. Populus). Am. J. Bot. 77, 11761187.

Sánchez Goñi, M.F., Hannon, G.E., 1999. High altitude vegetational pattern on Iberian Mountain Chain (north-central Spain) during the Holocene. Holocene 9, 39-57.

Storme, V., Boejeran, W., Vanden Broeck, A.H., Ivens, B., Halfmaerten, D., Van Slycken, J., Castiglione, S., Grassi, F., Fossati, T., Cottrell, J.E., Tabbener, H.E., Lefevre, F., Imbert, E., Fluch, S., Krustufek, V., Burg, K., Bordacs, S., Gebhardt, K., Vornam, B., Pohl, A., Alba, N., Bovenschen, J., van Dam, B., van der Schoot, J., Vosman, B., Smulders, M.J.M., 2004. Ex situ conservation of black poplar in Europe: duplications and diversity in nine genebank collections and their use for conservation and nature development. Theor. Appl. Genet. 108, 969-981.

Taberlet, P., Gielly, L., Pautou, G., Bouvet, J., 1991. Universal primers for amplification of three non-coding regions of chloroplast DNA. Plant Mol. Biol. 17, 1105-1109.

Taberlet, P., Fumagalli, L., Wust-Saucy, A.-G., Cousson, J.-F., 1998. Comparative phylogeography and postglacial colonization routes in Europe. Mol. Ecol. 7, 453-464.

Vietto, L. 2000. Update of the EUFORGEN core collection and the database of clones. In: Borelli, S., de Vries, S., Lefèvre, F., Turok, J. (Eds.), Report of the Sixth Meeting of the Populus nigra Network, pp. 26-28.

Vornam, B., Herzog, S., Preisig-Müller, R., Hattemer, H.H., 1994. Restriction fragment length polymorphisms of a chloroplast photosystem II gene from poplar and their use for species identification. Genome 37, 747-750.

Weising, K., Gardner, R., 1999. A set of PCR primers for the detection of simple sequence repeat polymorphisms in chloroplast genomes of dicotyledonous angiosperms. Genome 42, 919.

Zsuffa, L., 1974. The genetics of Populus nigra L. Ann. Forestales (Zagreb) 6/2:, 29-53. 